\title{
PENGARUH PENYULUHAN TERHADAP PENGETAHUAN DAN PRAKTIK GIZI SEIMBANG PADA ANAK SEKOLAH DASAR
}

\author{
Thresia Dewi Kartini $^{1}$, Manjilala ${ }^{1}$, Suri Etika Yuniawati \\ ${ }^{1}$ Jurusan Gizi, Politeknik Kesehatan Kemenkes, Makassar \\ ${ }^{2}$ Alumni Jurusan Gizi, Politeknik Kesehatan Kemenkes, Makassar \\ *) E-mail thresiadewi72@gmail.com/08242054419
}

\begin{abstract}
Nutrition counseling using the slogan 4 Healthy 5 Perfect since 1952, began to undergo changes into the General Guidelines for Balanced Nutrition (PUGS) in 1992. Counseling about health and nutrition to the community is not an easy thing because it involves behavior change. Reduced knowledge will also reduce a person's ability to apply nutritional information to everyday life. School children are the next generation of the nation and constitute development capital, so that their health needs to be improved. This study aims to determine the effect of counseling on balanced nutrition knowledge and practices in children of Mandai Elementary School in Makassar City. This study wanted to see the effect of balanced nutrition counseling on a group before and after intervention. This research is an analytical study with quasi-experimental design (quasi experimental), one group pretest posttest design approach. The sample is the fifth grade students in the Mandai Elementary School in Makassar City who were selected by simple random sampling of 46 samples. Data on balanced nutrition knowledge and balanced nutrition practices before and after counseling were obtained through interviews using questionnaires. Data analysis using the Wilcoxon test. Data is presented using tables and narratives.The results showed that there was an influence of knowledge $(p=0,000)$ and balanced nutrition practices $(p=0,001)$ of school children before and after counseling. It is recommended for schools, especially teachers, to be able to socialize repetitive balanced nutrition guidelines through empowering School Health Enterprises (SHE).
\end{abstract}

Keywords: Counseling, Knowledge and Practices of Balanced Nutrition

\section{PENDAHULUAN}

Bangsa dikatakan maju jika memiliki tingkat kesehatan, kecerdasan, dan produktivitas kerja yang tinggi. Ketiga hal ini dipengaruhi oleh keadaan gizi. Bukti empiris menunjukkan bahwa sumber daya manusia (SDM) yang berkualitas ditentukan oleh status gizi yang baik dan konsumsi pangan yang sehat. Kedua hal tersebut penting karena seseorang tidak dapat mengembangkan kapasitasnya secara maksimal apabila yang bersangkutan tidak memiliki status gizi dan kesehatan yang optimal (Kemenkes, 2014).

Perbaikan keadaan gizi penting untuk meningkatkan kesehatan, menurunkan angka kematian, meningkatkan kemampuan tumbuh kembang, fisik, mental, sosial anak, produktivitas kerja serta prestasi akademik. Salah satu faktor yang mempengaruhi status gizi seseorang adalah pengetahuan individu tersebut tentang gizi. Terjadinya permasalahan gizi dan sikap tentang gizi yang 
kurang baik pada anak sekolah dasar salah satunya disebabkan oleh kurangnya pengetahuan gizi (Notoatmodjo, 2007). Hasil penelitian Tuzzahroh F (2015) di SDN Karangasem 111 menunjukkan presentasi anak sekolah dasar dengan pengetahuan kategori kurang sebesar 29,4\%, baik sebesar 5,9\% dan kategori cukup sebesar 64,7\%. Hasil penelitian Maulana, dkk (2012), di SD Inpres Lasusua menunjukkan bahwa 53,7\% tingkat pengetahuan anak tentang gizi tergolong kurang.

Penyuluhan gizi dengan slogan 4 Sehat 5 Sempurna yang dimulai tahun 1952, sudah tidak sesuai lagi dengan perkembangan ilmu dan permasalahan gizi dewasa ini, sehingga perlu diperbarui dengan slogan dan visual yang sesuai dengan kondisi saat ini. Prinsip Nutrition Guide for Balanced Diet hasil kesepakatan konferensi pangan sedunia di Roma Tahun 1992 diyakini mampu mengatasi beban ganda masalah gizi, baik kekurangan maupun kelebihan gizi. Di Indonesia prinsip tersebut dikenal dengan Pedoman Gizi Seimbang (PGS) (Kemenkes, 2014).

Pendidikan dan penyuluhan tentang kesehatan dan gizi kepada masyarakat bukan merupakan hal yang mudah karena menyangkut perubahan perilaku. Berkurangnya pengetahuan juga akan mengurangi kemampuan seseorang untuk menerapkan informasi gizi dalam kehidupan sehari-hari (Nuryanto, 2014). Hasil penelitian Mulyani EY (2014) di SDN GU 12 Pagi perilaku responden dengan kategori "Ya, menerapkan gizi seimbang" sebanyak 13 atau $38,2 \%$ dan yang "tidak menerapkan gizi seimbang" sebanyak 16 responden atau sebanyak 55,2\%. Hasil penelitian Meriska (2014) menunjukkan bahwa anak sekolah dasar yang melakukan sarapan pagi adalah sebesar $52.8 \%$, sedangkan yang tidak sarapan pagi adalah sebesar $47.2 \%$. Penelitian Daruwati MS (2017) di SD Pantekosta
Magelang menunjukkan anak sekolah yang mengonsumsi sayur dengan kategori cukup sebesar 32,6\% dan yang mengonsumsi sayur dengan kategori kurang sebesar $67,4 \%$. Pelaksanaan cuci tangan di SD MI Muhammadiyah Sebagian besar responden adalah kategori kurang sebanyak 52\%, kategori cukup sebanyak $28 \%$, dan kategori baik sebanyak 19\% (Hadi, AM, 2017). Datadata hasil penelitian diatas menunjukkan bahwa sebagian besar anak sekolah dasar belum sesuai dalam mempraktikkan pedoman gizi seimbang.

Anak sekolah merupakan generasi penerus bangsa dan merupakan modal pembangunan, sehingga tingkat kesehatannya perlu dibina dan ditingkatkan. Upaya kesehatan tersebut adalah perbaikan gizi terutama diusia sekolah dasar yaitu usia 7-12 tahun. Perbaikan gizi anak sekolah dasar merupakan langkah strategis karena dampaknya secara langsung berkaitan dengan pencapaian SDM yang berkualitas (Tuzzahroh F, 2015).

Berdasarkan data di atas, maka penulis melakukan penelitian tentang pengaruh penyuluhan terhadap pengetahuan dan praktik gizi seimbang pada anak SD Negeri Mandai Kota Makassar. Adapun pertimbangan wilayah yang dijadikan tempat penelitian adalah sekolah dasar yang belum pernah diberikan penyuluhan gizi seimbang, yang merupakan hasil wawancara terhadap kepala sekolah pada observasi awal.

\section{METODE PENELITIAN}

Jenis penelitian yang dilakukan merupakan penelitian analitik dengan desain eksperimen semu (quasi eksperimental) yang bertujuan untuk menganalisis pengaruh penyuluhan terhadap perubahan pengetahuan dan praktik gizi seimbang pada anak SD Negeri Mandai Kota Makassar, menggunakan pendekatan one group pretest posttest design. 
Populasi pada penelitian ini adalah seluruh siswa kelas $\mathrm{V}$ berjumlah 84 orang yang terdiri dari kelas A dan B. Besar sampel dihitung dan dipilih secara simple random sampling dengan kriteria inklusi yaitu, terdaftar sebagai siswa kelas V di SD Negeri Mandai, hadir pada saat penelitian dan bersedia menjadi sampel, sehingga besar sampel sebanyak 46 sampel.

Data primer yang dikumpulkan yaitu identitas, pengetahuan dan praktik anak sekolah tentang PGS. Data pengetahuan gizi seimbang sebelum dan sesudah penyuluhan diperoleh dengan menggunakan kuesioner. Data praktik gizi seimbang sebelum dan sesudah penyuluhan diperoleh melalui wawancara. Data pengetahuan sampel diolah dengan menjumlah skor setiap sampel yang telah ditentukan, yaitu skor 1 untuk jawaban benar dan skor 0 untuk jawaban salah. Kemudian nilai ditentukan sesuai kriteria objektif, yaitu, baik apabila jawaban kuesioner benar lebih besar dari nilai rata-rata dan kurang apabila jawaban kuesioner benar kurang dari atau sama dengan nilai rata-rata. Data praktik sampel diolah dengan menjumlah skor setiap sampel, yaitu skoring tertinggi 4 dan skoring terendah 1. Kemudian nilai ditentukan sesuai kriteria objektif, yaitu baik apabila nilainya $>60 \%$ dan kurang apabila nilainya $\leq 60 \%$. Data yang telah diperoleh terdistribusi tidak normal, sehingga analisis data yang digunakan adalah uji Wilcoxon. Data disajikan dalam bentuk tabel, diagram dan narasi dengan berpedoman pada teori-teori dan hasil penelitian yang sesuai.

\section{HASIL PENELITIAN}

Perilaku Sampel Sebelum dan Sesudah diberikan Penyuluhan Gizi Seimbang

Tabel 02 menunjukkan bahwa perilaku sampel setelah penyuluhan gizi seimbang seperti sarapan pagi mengalami kenaikan yaitu dari 90\% menjadi 92\%, namun mengalami penurunan pada praktik membawa bekal yaitu dari $13 \%$ menjadi $9 \%$.

Tabel 02

Perilaku Sampel Sebelum dan Sesudah diberikan Penyuluhan Gizi Seimbang

\begin{tabular}{|c|c|c|c|c|}
\hline \multirow[t]{2}{*}{ Praktik Gizi Seimbang } & \multicolumn{2}{|c|}{$\begin{array}{c}\text { Sebelum } \\
(n=46)\end{array}$} & \multicolumn{2}{|c|}{$\begin{array}{c}\text { Sesudah } \\
(\mathrm{n}=46)\end{array}$} \\
\hline & $\mathrm{n}$ & $\%$ & $\mathrm{n}$ & $\%$ \\
\hline \multicolumn{5}{|l|}{ Sarapan Pagi } \\
\hline $\mathrm{Ya}$ & 41 & 90 & 42 & 92 \\
\hline Tidak & 5 & 10 & 4 & 8 \\
\hline \multicolumn{5}{|l|}{ Membawa Bekal } \\
\hline $\mathrm{Ya}$ & 6 & 13 & 4 & 9 \\
\hline Tidak & 40 & 87 & 42 & 91 \\
\hline \multicolumn{5}{|l|}{ Membawa Uang Saku } \\
\hline $\mathrm{Ya}$ & 46 & 100 & 46 & 100 \\
\hline Tidak & 0 & 0 & 0 & 0 \\
\hline \multicolumn{5}{|l|}{ Jumlah Uang Saku } \\
\hline$>10.000,00$ & 25 & 54 & 27 & 58 \\
\hline$\leq 10.000,00$ & 21 & 46 & 19 & 42 \\
\hline
\end{tabular}


Pengetahuan Sebelum dan Sesudah Penyuluhan Gizi Seimbang

Tabel 03

Pengetahuan Sebelum dan Sesudah Penyuluhan Gizi Seimbang

\begin{tabular}{|c|c|c|c|c|c|}
\hline \multirow{2}{*}{$\begin{array}{c}\text { Pengetahuan Gizi } \\
\text { Seimbang }\end{array}$} & \multicolumn{2}{|c|}{ Sebelum } & \multicolumn{2}{|c|}{ Sesudah } & \multirow{2}{*}{$P$} \\
\hline & $\mathrm{n}$ & $\%$ & $\mathrm{n}$ & $\%$ & \\
\hline Baik & 24 & 52 & 25 & 54 & \multirow{2}{*}{0,000} \\
\hline Kurang & 22 & 48 & 21 & 46 & \\
\hline Total & 46 & 100 & 46 & 100 & \\
\hline
\end{tabular}

Tabel 03 menunjukkan bahwa sampel memiliki pengetahuan gizi seimbang yang baik sebelum intervensi yaitu $52 \%$ dan sesudah intervensi yaitu 54\%. Hasil analisis statistik Wilcoxon menunjukkan bahwa ada pengaruh penyuluhan gizi seimbang terhadap perubahan pengetahuan sebelum dan sesudah dengan nilai $(p=0,000<0,05)$.
Tabel 04 menunjukkan bahwa sampel memiliki praktik gizi seimbang yang baik sebelum intervensi yaitu $98 \%$ dan sesudah intervensi yaitu $100 \%$. Adapun hasil analisis statistik Wilcoxon menunjukkan bahwa ada pengaruh penyuluhan gizi seimbang terhadap perubahan praktik sebelum dan sesudah dengan nilai $(p=0,001<0,05)$.

Praktik Sebelum dan Sesudah Penyuluhan Gizi Seimbang

Tabel 04

Praktik Sebelum dan Sesudah Penyuluhan Gizi Seimbang

\begin{tabular}{|c|c|c|c|c|c|}
\hline \multirow{2}{*}{ Praktik Gizi Seimbang } & \multicolumn{2}{|c|}{ Pebelum } & \multicolumn{2}{|c|}{ Sesudah } & \multirow{2}{*}{$P$} \\
\hline & $\mathrm{n}$ & $\%$ & $\mathrm{n}$ & $\%$ & \\
\hline Baik & 45 & 98 & 46 & 100 & \multirow{2}{*}{0,001} \\
\hline Kurang & 1 & 2 & 0 & 0 & \\
\hline Total & 46 & 100 & 46 & 100 & \\
\hline
\end{tabular}

\section{PEMBAHASAN}

Pengetahuan dapat diperoleh dengan berbagai cara, seperti mengikuti pendidikan, pelatihan, seminar atau membaca. Pengetahuan erat kaitannya dengan pendidikan dan pendidikan tidak terlepas dari proses belajar mengajar. Pendidikan gizi melalui penyuluhan pada anak sekolah dasar harus dilakukan dengan media yang menarik agar penyampaian materi dapat lebih diterima dengan mudah. Metode penyampaian penyuluhan yang dilakukan dalam penelitian ini menggunakan media power point. Penelitian yang dilakukan Irnani $\mathrm{H}$ dan Sinaga T (2017) menggunakan teknik ceramah dengan media power point yang diberikan sekali dan beberapa materi yang diberikan hanya disampaikan secara lisan.

Hasil penelitian pengetahuan gizi seimbang secara deskriptif menunjukkan adanya kenaikan. Pengetahuan gizi seimbang sebelum diberikan penyuluhan gizi seimbang 
yaitu baik 24 siswa (52\%) dan setelah penyuluhan gizi yaitu 25 siswa (54\%). Adanya peningkatan pengetahuan gizi siswa setelah diberikan penyuluhan gizi menunjukkan bahwa ada pengaruh pemberian penyuluhan gizi terhadap perubahan pengetahuan gizi yang dimiliki oleh siswa. Hipotesis ini diperkuat oleh uji statistik Wilcoxon dengan nilai $p=0,000$ $(p<0,05)$. Hal ini sejalan dengan penelitian yang dilakukan oleh Nuryanto,dkk (2014) pada SDN 01 Tembalang Kecamatan Tembalang Kota Semarang, bahwa ada pengaruh pendidikan gizi terhadap pengetahuan anak SD tentang gizi anak sekolah dengan hasil uji statistik nilai $p$ value $=0,001<0,05$.

Alat bantu dalam penyuluhan akan semakin menarik dalam kemasan materi yang disampaikan dalam ceramah. Penggunaan alat bantu visual efektif dalam meningkatkan pengetahuan karena dengan alat bantu visual lebih mudah dalam cara penyampaian dan penerimaan informasi. Notoadmodjo (2007) menjelaskan alat peraga atau media penyuluhan disusun berdasarkan prinsip pengetahuan pada manusia diterima dengan panca indera. Semakin banyak yang digunakan untuk menerima sesuatu maka semakin banyak dan semakin jelas pula pengertian atau pengetahuan yang diperoleh sehingga mempermudah pemahaman.

Hasil penelitian oleh Irnani $\mathrm{H}$ dan Sinaga T (2017) menjelaskan bahwa, nilai pengetahuan siswa kurang disebabkan karena dipengaruhi oleh faktor internal, eksternal, dan teknik atau metode belajar yang berbedabeda yang dimiliki oleh setiap anak. Faktor internal yang mempengaruhi terdiri atas fisik dan psikis subjek. Aspek fisik meliputi keadaan alat indra, kesehatan jasmani, dan kondisi anggota tubuh. Aspek psikis meliputi tingkat kecerdasan, pembawaan, keadaan emosi, kemauan, daya fantasi, dan logika. Faktor eksternal yang dapat mempengaruhi subjek antara lain bunyi-bunyian, situasi atau kondisi ruangan (cahaya, temperatur, bau), serta orang-orang atau benda-benda di sekitar subjek yang mengganggu subjek saat proses mengerjakan kuesioner pengetahuan gizi.

Hasil penelitian oleh Ristraningsih GP (2017) pada siswi SMP Negeri 28 Semarang, sebanyak 24 responden $(42,1 \%)$ masih memiliki pengetahuan cukup, metode ceramah memiliki kekurangan yaitu apabila tidak diberikan secara baik mungkin responden akan mudah bosan. Suasana bosan ini lah yang mempengaruhi responden masih memiliki pengetahuan yang cukup.

Pengetahuan seseorang dipengaruhi oleh beberapa faktor antara lain adalah umur, dalam penelitian ini anak sekolah yang dijadikan sampel sebagian besar berumur 11 tahun yaitu 33 siswa (72\%) dan berumur 12 tahun yaitu 3 siswa (6\%), dalam rentang usia 11-16 tahun dimana dalam rentang usia tersebut anak sekolah masih sangat minim pengetahuan dan belum adanya pengalaman tentang gizi. Anak sekolah masih berpendidikan dasar (SD), namun perlu ditekankan bahwa seorang yang berpendidikan rendah tidak berarti mutlak berpengetahuan rendah pula. Peningkatan pengetahuan tidak mutlak diperoleh di pendidikan formal, akan tetapi juga dapat diperoleh pada pendidikan non formal, keterpaparan informasi, media, lingkungan dan sosial budaya (Ningsih, 2018).

Praktik merupakan respon dari sebuah rangsangan setelah seseorang mengetahui stimulus atau objek, kemudian melakukan penilaian terhadap objek tersebut dan selanjutnya dapat menerapkan pengetahuan baru yang dinilai baik bagi dirinya. Perubahan praktik seseorang terbentuk setelah ada perubahan pengetahuan serta sikap seseorang. Pemberian edukasi gizi yang dilakukan dengan pendekatan yang baik maka dapat meningkatkan pengetahuan dan sikap yang kemudian diikuti dengan 
perubahan praktik. Praktik baru akan terbentuk jika seseorang tahu terlebih dahulu terhadap stimulus yang ada yakni materi baru, sehingga muncul pengetahuan baru yang selanjutnya dapat menimbulkan respon dalam bentuk sikap seseorang yang diharapkan dari hasil sikap yang baik akan timbul praktik baru yang baik (Amalia dkk, 2018).

Hasil penelitian praktik gizi seimbang sebelum diberikan penyuluhan gizi seimbang kategori baik yaitu 45 siswa (98\%) sedangkan setelah penyuluhan gizi seimbang yaitu 46 siswa $(100 \%)$. Adanya peningkatan praktik gizi siswa setelah diberikan penyuluhan gizi menunjukkan bahwa ada pengaruh pemberian penyuluhan gizi terhadap perubahan praktik gizi yang dimiliki oleh siswa. Hipotesis ini diperkuat oleh uji statistik Wilcoxon dengan nilai $p=0,001(p<0,05)$. Hal ini sejalan dengan penelitian yang dilakukan oleh Hikmawati Z (2016) pada siswa SDN Poasia Kota Kendari, bahwa ada pengaruh sikap siswa/siswi tentang gizi seimbang sebelum dan sesudah diberikan penyuluhan dengan media promosi puzzle gizi dengan nilai $p=0,019(p<0,05)$. Adapun penelitian yang tidak sejalan, dilakukan oleh Asmarudin (2018) pada siswa SMP Negeri 35 Makassar, bahwa tidak ada pengaruh edukasi gizi terhadap kebiasaan jajan ditunjukkan dengan nilai $p=0,372(p>0,05)$.

Hasil penelitian dari uji statistik yang menunjukkan bahwa ada pengaruh penyuluhan terhadap praktik gizi seimbang, telah didukung melalui data perilaku gizi seimbang yang dilakukan secara deskriptif selama 6 hari berturut-turut pada pengukuran perilaku sarapan pagi sebelum intervensi yaitu 41 siswa (90\%) sedangkan setelah intervensi menjadi 42 siswa (92\%). Sedangkan jika dilihat dari perilaku membawa bekal ke sekolah mengalami penurunan, sebelum intervensi yaitu 6 siswa (13\%) sedangkan setelah intervensi yaitu 4 siswa (9\%). Hal tersebut terjadi karena berhubungan dengan peningkatan perilaku sarapan pagi. Siswa yang tidak sarapan pagi memiliki kebiasaan membawa bekal untuk dikonsumsi di sekolah. Namun, setelah diberikan penyuluhan gizi seimbang terdapat perubahan yaitu peningkatan pada perilaku sarapan pagi, sehingga siswa yang telah sarapan pagi dirumah tidak membawa bekal ke sekolah. Adapun siswa membawa uang saku yaitu 46 siswa (100\%) yang sebagian besar digunakan untuk membeli jajanan di sekolah dan sebagian siswa menggunakannya untuk biaya transportasi sekolah.

Lokasi yang dijadikan sebagai tempat penelitian merupakan daerah yang termasuk wilayah perkotaan. Sekolah tersebut berada dipinggir jalan raya Mandai dan dekat dengan bandara kota Makassar, sehingga sangat mudah untuk mendapatkan akses informasi. Amalia (2018) mengatakan lingkungan tempat tinggal juga ikut andil dalam menentukan praktik yang dilakukan oleh seseorang. Lingkungan yang baik akan mendukung seseorang dalam melakukan praktik yang baik pula. Begitu sebaliknya saat kondisi lingkungan kurang mendukung seseorang dalam melakukan perubahan praktik maka keputusan untuk melakukan perubahan praktik juga akan terhambat.

\section{KESIMPULAN}

1. Anak sekolah dasar sebagian besar lakilaki $57 \%$ dan berumur 11 tahun $72 \%$.

2. Tingkat pengetahuan anak sekolah dasar tentang gizi seimbang sebelum diberikan penyuluhan gizi yaitu baik $52 \%$ dan sesudah diberikan penyuluhan gizi yaitu baik dengan $54 \%$.

3. Praktik anak sekolah dasar tentang gizi seimbang sebelum diberikan penyuluhan gizi yaitu baik $98 \%$ dan sesudah diberikan penyuluhan gizi yaitu baik dengan persentase $100 \%$.

4. Ada pengaruh pengetahuan $(p=0,000)$ dan praktik gizi seimbang $(p=0,001)$ pada anak 
sekolah sebelum dan sesudah diberikan penyuluhan gizi seimbang.

\section{SARAN}

1. Bagi pihak sekolah terutama guru, diharapkan dapat memberikan penyuluhan ataupun sosialisasi mengenai pedoman gizi seimbang secara berulang melalui pemberdayaan Usaha Kesehatan Sekolah (UKS).

2. Bagi siswa-siswi, diharapkan dapat menerapkan sepenuhnya praktik pada pedoman gizi seimbang dalam hidup sehari-hari.

3. Bagi peneliti berikutnya, perlu mengadakan penelitian yang berkaitan dengan pengaruh penyuluhan terhadap pengetahuan dan praktik gizi seimbang di sekolah dasar, dan beberapa faktor lain yang mempengaruhi praktik anak dalam pedoman gizi seimbang.

\section{DAFTAR PUSTAKA}

Amalia F, Nugraheni SA, dan Kartini A. (2018). Pengaruh Edukasi Gizi terhadap Pengetahuan dan Praktik Calon Ibu dalam Pencegahan Kurang Energi Kronik Ibu Hamil. Jurnal Kesehatan Masyarakat (e-Journal) Volume 6, Nomor 5, Oktober 2018 (ISSN: 2356-3346)

Asmarudin P, Chaerunnimah, dan Rahmiati R. (2018). Edukasi Gizi terhadap Pengetahuan dan Kebiasaan Jajan pada Siswa SMP Negeri 35 Makassar. Media Gizi Pangan, Vol. 25, Edisi 1, 2018

Daruwati MS. (2017). Hubungan Konsumsi Sayur dan Buah dengan Obesitas pada Anak SD Kelas IV-VI di SD Pantekosta Magelang Tahun 2017. Jurnal. Poltekkes Kemenkes Yogyakarta.

Hadi, AM. (2017). Gambaran Pengetahuan dan Pelaksanaan Cuci Tangan pada
Siswa Sekolah Dasar di MI Muhammadiyah Argosari Kecamatan Ayah Kabupaten Kebumen. Skripsi. Program Studi S1 Keperawatan STIKES Muhammadiyah Gombong. Hikmawati Z, Yasnani, dan Sya'ban AR. (2016). Pengaruh Penyuluhan dengan Media Promosi Puzzle Gizi terhadap Perilaku Gizi Seimbang pada Siswa Kelas V di SD Negeri 06 Poasia Kota Kendari. Fakultas Kesehatan Masyarakat Universitas Haluleo.

Irnani H dan Sinaga T. (2017). Pengaruh Pendidikan Gizi terhadap Pengetahuan Praktik Gizi Seimbang dan Status Gizi pada Anak Sekolah Dasar. Jurnal Gizi Indonesia (The Indonesian Journal of Nutrition), 6 (1).

Kemenkes. (2014). Pedoman Gizi Seimbang. Jakarta; Kementrian Kesehatan Republik Indonesia.

Maulana, Sirajuddin S, Najamuddin U. (2012). Pengaruh Penyuluhan terhadap Pengetahuan Gizi dan Pola Konsumsi pada Siswa SD Inpres Lasusua Kabupaten Kolaka Utara. Skripsi. Makassar: FKM Universitas Hasanuddin.

Meriska. (2014). Perilaku Sarapan Pagi Anak Sekolah Dasar. 92 Jurnal Kesehatan, Volume V, Nomor 1, April 2014, hlm 90-97. Lampung. Program Pascasarjana Kesehatan Masyarakat Stikes Mitra Lampung

Mulyani EY (2014). Pengetahuan, Sikap, dan Perilaku Gizi Seimbang Anak Sekolah Dasar di SDN GU 12 Pagi. Jurnal Abdimas Vol. 1 No. 1 September 2014. Jakarta: Universitas Esa Ungggul.

Ningsih. (2018). Pengaruh Edukasi Pedoman Gizi Seimbang terhadap Pengetahuan dan Sikap Remaja Putri Kurus. 
JOMIS (Journal Of Midwifery Science) Vol 2. No.2, Juli 2018.

Nuryanto, dkk. (2014). Pengaruh Pendidikan

Gizi terhadap Pengetahuan dan Sikap tentang Gizi Anak Sekolah Dasar. Jurnal Gizi Indonesia; Vol.3 No.1 Desember 2014. Universitas Dipenogoro.

Notoatmodjo, S. (2007). Promosi Kesehatan dan Ilmu Perilaku. Jakarta: PT Rineka Cipta.

Ristraningsih GP. (2017). Pengaruh Pendidikan Kesehatan terhadap Tingkat Pengetahuan Kesehatan Reproduksi Remaja pada Siswi Kelas VIII di SMP Negeri 28 Semarang. Skripsi. Fakultas Ilmu Kesehatan Universitas Muhammadiyah Surakarta.

Tuzzahroh F. (2015). Pengaruh Penyuluhan Gizi Seimbang dengan Media Visual, Poster dan Permainan Kwartet Gizi terhadap Pengetahuan Gizi dan Status Gizi Siswa di Sekolah Dasar Negeri Karangasem III Kota Surakarta. Skripsi. Surakarta: Universitas Muhammadiyah Surakarta. 